\title{
A Preliminary Investigation on the Chemical Composition of the Cell Surface of Five Enteropathogenic Escherichia coli Serotypes
}

\author{
Adriana Hamond Regua Mangia/*/**/+, Eliana Barreto Bergter*, \\ Lúcia Martins Teixeira*, Fernando Costa e Silva Filho
}

Instituto de Biofísica Carlos Chagas Filho *Instituto de Microbiologia, Universidade Federal do Rio de Janeiro, Rio de Janeiro, RJ, Brasil **Escola Nacional de Saúde Pública, Fundação Oswaldo Cruz, Rua Leopoldo Bulhões, 1480 - 60 andar, 21041-210 Rio de Janeiro, RJ, Brasil

The cell surfaces of five enteropathogenic Escherichia coli serotypes (O111:H2; O111:H12; O125:H9; O119:H6; O26:H11) were assayed by chemical methods, lectin agglutination tests and spectroscopy associated to transmission electron microscopy. Results of lectin agglutination assays showed that all strains reacted with mannose-binding lectins. Strains belonging to serotype O125:H9 also agglutinated with lectins which recognize galactose and $\mathrm{N}$-acetyl-galactosamine residues. The bacterial cells were treated with 0.01M phosphate buffered saline ( $\mathrm{pH} \mathrm{7.0)}$ at $100^{\circ} \mathrm{C}$ for $2 \mathrm{hr}$ and the extracts were submitted to precipitation and fractionated by Cetavlon. Phosphate, total sugar and protein contents were determined. Gas liquid chomatography-mass spectrometry analysis of alditol acetates showed the presence of galactose, mannose, fucose, glucose and traces of ribose. Spectroscopic analysis of intact cells showed the presence of a capsule-like structure which was not totally preserved after extraction. Some cells were still surrounded by an amorphous capsular-like material after polysaccharide extraction.

Key words: enteropathogenic Escherichia coli - cell surface - lectins

Enteropathogenic Escherichia coli (EPEC) is a leading cause of diarrhea in children living in developing countries, especially among infants from 6 months to 1 year old (Gomes et al. 1989, Regua et al. 1990, Albert et al. 1995, Tamura et al. 1996). Although diarrhea is often severe and protracted, EPEC virulence factors are not completely well understood (Baldwin 1998).

Bacterial adhesion to intestinal epithelial cells has been considered an important step for the pathogenicity of EPEC serotypes leading to ultrastructural and functional changes (Donnenberg et al. 1998). It has been observed that EPEC strains present multifactorial virulence mechanisms and chemical and physical properties of their surfaces are assumed to be related to pathogenicity (Orskov et al. 1977). In nature, bacteria adhere to different substrata by a mass of tangled polysaccharides fi-

\footnotetext{
This work was supported by the Financiadora de Estudos e Projetos (Finep), Conselho Nacional de Desenvolvimento Científico e Tecnológico (CNPq), and Fundação de Amparo a Pesquisa do Estado do Rio de Janeiro (Faperj).

${ }^{+}$Corresponding author. Fax. + 55-21-564.8985. E-mail: immmtml@microbio.ufrj.br

Received 25 June 1998

Accepted 2 March 1999
}

bers, a component outside the cell wall (Costerton et al. 1978). This exopolysaccharide network mediates adhesion of bacteria to various substrata, including certain epithelial surfaces of the human host (Peterson \& Quie 1981). On the other hand, extracellular capsular polysaccharides of different bacteria, including E. coli, have been frequently associated with diseases (Muhldorfer \& Hacker 1994)

The aim of the present study was to investigate and compare the chemical nature of exopolysaccharides isolated from different $E$. coli serotypes. The cellular topology of these components was also assayed by transmission electron microscopy.

\section{MATERIALS AND METHODS}

Strains - EPEC strains belonging to five different serotypes (O111:H2; O111:H12; O125:H9; O119:H6 and O26:H11) were analyzed. They were selected on the basis of the frequency of serotypes isolated during a study previously performed in our laboratory (Regua Mangia et al. 1993). For all experiments, bacteria cells were grown in brain heart infusion broth (BHI; Difco Laboratories, Detroit, Michigan, USA) for $18 \mathrm{hr}$.

Lectin agglutination - Agglutination tests were performed in 96-well, round bottom microtiter plates (Takatsy microtiter plates; Cooke Engineering Co., Alexandria, Virginia, USA), using a pro- 
cedure based on that described by Wong et al. (1986) and the 17 lectins listed in Table I. For that, equal volumes $(0.025 \mathrm{ml})$ of bacterial cells suspensions $\left(2 \times 10^{8}\right.$ bacteria $\left./ \mathrm{ml}\right)$ and lectin solutions $(0.24$ to $1000 \mu \mathrm{g} / \mathrm{ml})$ were mixed and incubated at room temperature or at $4^{\circ} \mathrm{C}$ for 1 and $2 \mathrm{hr}$, respectively. Cell agglutination was scored by visual inspection.

Extraction and purification of the capsular polysaccharide - Capsular polysaccharide were extracted as previously described (Lloyd 1970). Briefly, strains were grown in $250 \mathrm{ml}$ of BHI and, after centrifugation, $3 \mathrm{vol}$ of ethanol were added to the supernatant to precipitate the polysaccharides. Precipitates were redissolved in water and reprecipitated three times with ethanol. The crude polymers were fractionated by stepwise precipitation with hexadecyltrimethylammonium bromide (Cetavlon) at pH 7.0 (Fraction A) and Cetavlonborate at $\mathrm{pH} 8.8$ (Fraction $\mathrm{B}$ ). Polysaccharides in Fraction B were recovered from the Cetavlon-borate complex by treatment with glacial acetic acid and reprecipitation with $3 \mathrm{vol}$ of ethanol. The resulting precipitate was removed by centrifugation and washed with $2 \%$ acetic acid in ethanol and then ethanol only. Fraction $\mathrm{C}$ was obtained by adjusting the $\mathrm{pH}$ of the supernatant to $\mathrm{pH} 9.5$ with $2 \mathrm{~N}$ $\mathrm{NaOH}$ and the product was isolated as for Fraction B. The fractions were acidified, dialyzed, evaporated to a small volume and the resulting polymers were precipitated with excess ethanol, and then isolated. The different fractions obtained were submitted to both analytical and chemical methods.

Analytical methods - Total carbohydrate contents was determined by the phenol sulfuric acid assay (Dubois et al. 1956). Total protein contents was determined according to Lowry et al. (1951), and phosphate contents by the procedure recommended by Ames (1966).

Determination of polysaccharide composition - Fractions A, B, and C were hydrolyzed with 0.5 $\mathrm{M}$ sulfuric acid for $18 \mathrm{hr}$ at $100^{\circ} \mathrm{C}$ and the resulting monosaccharides were examined as their alditol acetates by gas liquid chromatography-mass spectrometry (GC-MS) (Sawadeker et al. 1965). The chromatographic separation was carried out by using a $30 \mathrm{~m} \times 0.25 \mathrm{~mm}$ glass capillary columm containing OV-225, programmed to $50-220^{\circ} \mathrm{C}$ at $50^{\circ} \mathrm{C} / \mathrm{min}$, and hold. Helium was used as the carrier gas at a linear speed of $40 \mathrm{~cm} / \mathrm{sec}$.

Ultrastructural cytochemistry - Bacterial cells were fixed or not with $2.5 \%$ glutaraldehyde, washed with $0.1 \mathrm{M}$ phosphate buffer for $60 \mathrm{~min}$ at room temperature and at $4{ }^{\circ} \mathrm{C}$. The washed cells were then incubated in a solution containing 100 $\mathrm{mg} / \mathrm{ml}$ of cationized ferritin (Sigma Chemical Co.,
St. Louis, Missouri, USA) for $60 \mathrm{~min}$ at room temperature and at $4^{\circ} \mathrm{C}$. Subsequently, they were washed, post-fixed in $1 \%$ osmium tetroxide, dehydrated in acetone and embedded in Epon (Dannon et al. 1972). The resulting thin sections were examined by transmission electron microscopy in a CEM 902 Zeiss electron microscope.

Electron spectroscopic imaging - A drop of concentrated bacteria (before and after extraction) was placed on a formvar coated grid. The grid was air-dried. Electron spectroscopic imaging was carried out on a CEM 902 Zeiss electron microscope operated at $80 \mathrm{kv}$ with a $15 \mu \mathrm{m}$ objective aperture and an energy less acceptance window of $20 \Delta \mathrm{eV}$ for the so called zero loss filtered or elastic bright field image. Contrast tuning was achieved by altering the energy losses of the electrons used to form the microscope image. Electrons with particular energy losses were used to form the image of thick specimens, obtaining variations on contrast which helped in the observation of some structures as proposed by Bauer (1988).

\section{RESULTS}

Results of lectin agglutination tests are shown in Table I. All strains agglutinated in the presence of most mannose binding lectins, although high concentrations were required. By contrast, concentrations as low as $0.24 \mu \mathrm{g} / \mathrm{ml}$ of Bauhinia purpurea lectin agglutinated serotype 0125:H9 E. coli. Microorganisms belonging to this serotype also agglutinated in the presence of Glicine max, Wisteria floribunda and Ricinus communis I lectins, and reacted with Lotus tetragonolobus and Ulex europaeus I (fucose-binding lectins) as well. No agglutination was detected with the other lectins tested as indicated in Table I.

The chemical composition of fractions obtained from bacterial cells belonging to five different EPEC serotypes was determined by GC-MS and colorimetric methods. Analysis of the fractions showed variation in their total carbohydrate, protein and phosphate values; however, Fractions A derived from all EPEC serotypes yielded higher contents than that of the other fractions. Colorimetric analysis of Fractions A (Table II) revealed that values of total carbohydrate range from $29 \%$ to $61 \%$, protein from $8.5 \%$ to $25 \%$ and phosphate from $5 \%$ to $8.5 \%$. Carbohydrates were also found in Fraction B obtained from serotype O125:H9 (63\%), and in Fractions C from EPEC serotypes O125:H9 (19\%) and O119:H6 (51\%). Proteins were detected in Fraction B from serotype O125:H9 (28\%) and in Fractions C obtained from serotypes O125:H9 and O119:H6 with contents of $61 \%$ and $57 \%$, respectively.

GC-MS analysis showed that galactose and 
TABLE I

Agglutination of enteropathogenic Escherichia coli (EPEC) serotypes by lectins of various specificities

\begin{tabular}{|c|c|c|c|c|c|c|}
\hline \multirow[t]{2}{*}{ Lectin } & \multirow[t]{2}{*}{ Specificity } & \multicolumn{5}{|c|}{ EPEC serotype $^{a}$} \\
\hline & & O111:H2 & O111:H12 & O125:H9 & O119:H6 & O26:H11 \\
\hline Wheat germ agglutinin & $\beta$-GlcNAc; $\alpha$-NeuAc & & & & & \\
\hline Bauhinia purpurea & $\alpha$-GalNAc; $\beta$-GalNAc & & & 0.24 & & \\
\hline Glicine max & $\alpha$-GalNAc & & & 7.80 & & \\
\hline Wisteria floribunda & $\alpha$-GalNAc & & & 7.80 & & \\
\hline Ricinus communis & $\beta$-GalNAc; D-Gal & & & 15.60 & & \\
\hline Dolichos biflorus & $\alpha$-GalNAc & & & & & \\
\hline Vicia villosa & $\beta$-GalNAc; D-Mannose & & & & & \\
\hline Jacaline & D-Gal & & & & & \\
\hline Concanavalin A & D-Mannose & 125 & 125 & 125 & 125 & 125 \\
\hline Lens culinaris & $\alpha$-D-Mannose; $\alpha$-Gli; & & & & & \\
\hline & $\alpha$-GluNAc & 31 & 125 & 16 & 125 & 125 \\
\hline Canavalia bonariensis & D-Mannose & 250 & & 31 & 250 & \\
\hline Lotus tetragonolobus & $\alpha$-Fucose & & & 250 & & \\
\hline Ulex europaeus I & L-Fucose & & & 250 & & \\
\hline Phaseolus lunatus & $\alpha$-GalNAc & & & & & \\
\hline Ulex europaeus II & $\beta$-GluNAc & & & & & \\
\hline Solanum tuberosum & $\beta$-GluNAc & & & & & \\
\hline Limulus polyphemus & $\alpha-\mathrm{NeuAc}$ & & & & & \\
\hline
\end{tabular}

$a$ : values (in $\mu \mathrm{g} / \mathrm{ml}$ ) are relative to the minimal concentration required for agglutination.

TABLE II

Colorimetric analysis of Fractions A obtained by Cetavlon fractionation of different enteropathogenic Escherichia coli (EPEC) serotypes

\begin{tabular}{lccccc}
\hline Content (\%) & \multicolumn{5}{c}{ EPEC serotypes } \\
\cline { 2 - 6 } & O111:H2 & O111:H12 & O125:H9 & O119:H6 & O26:H11 \\
\hline Carbohydrate & 50.0 & 61.0 & 29.0 & 38.0 & 33.0 \\
Protein & 13.0 & 25.0 & 15.0 & 13.0 & 8.5 \\
Phosphate & 8.5 & 7.5 & 5.0 & 6.0 & 5.0 \\
\hline
\end{tabular}

mannose were the predominant monosaccharide components present in most of the serotypes studied. The crude polysaccharide preparation from serotype O125:H9 was fractionated into two components. Fraction B contained 53\% of galactose, $45 \%$ of mannose and $28.5 \%$ of peptide. Mannose and galactose in a ratio of $1: 1$ were found in Fraction C. This fraction had a peptide content (61\%) higher than that of the fraction B. Mannose, galactose and glucose in a ratio of 1:1:1 and traces of ribose and fucose were found in the capsular polysaccharide from serotype O119:H6 strain. Glucose and traces of ribose were present in serotype O26:H11. Neutral monosaccharide were not found in Fractions $\mathrm{B}$ and $\mathrm{C}$ obtained from serotypes O111:H2 and O111:H12.

Data from ultrastructural cytochemistry studies showed no labeling with cationized ferritin in bacteria collected after incubation at $37^{\circ} \mathrm{C}$ or $4^{\circ} \mathrm{C}$ either in glutaraldehyde-fixed or in nonfixed cells (Fig. 1).

Analysis of intact bacteria on coated grids showed the presence of a continuous and thick surface material outside the cell wall observed by conventional transmission electron microscopy (Fig. 2) and clearly demonstrated by using inelastic images of whole bacteria (Fig. 3). This material resembling a capsule-like structure was observed surrounding individual or colony cells. After extraction, this structure was partially lost and an amorphous capsular material remained surrounding some of the bacteria cells (Fig. 4).

\section{DISCUSSION}

Electron microscopy images of the EPEC strains studied showed a continuous structure around the bacterial cells closely resembling a capsule. Furthermore, spectroscopic images of bacteria collected after hot extraction, additionality suggested the capsular nature of the such material. $E$. coli capsular polysaccharides ( $\mathrm{K}$ antigens) are arranged into several distinct serotypes and many structures of the repeating units have been reported 


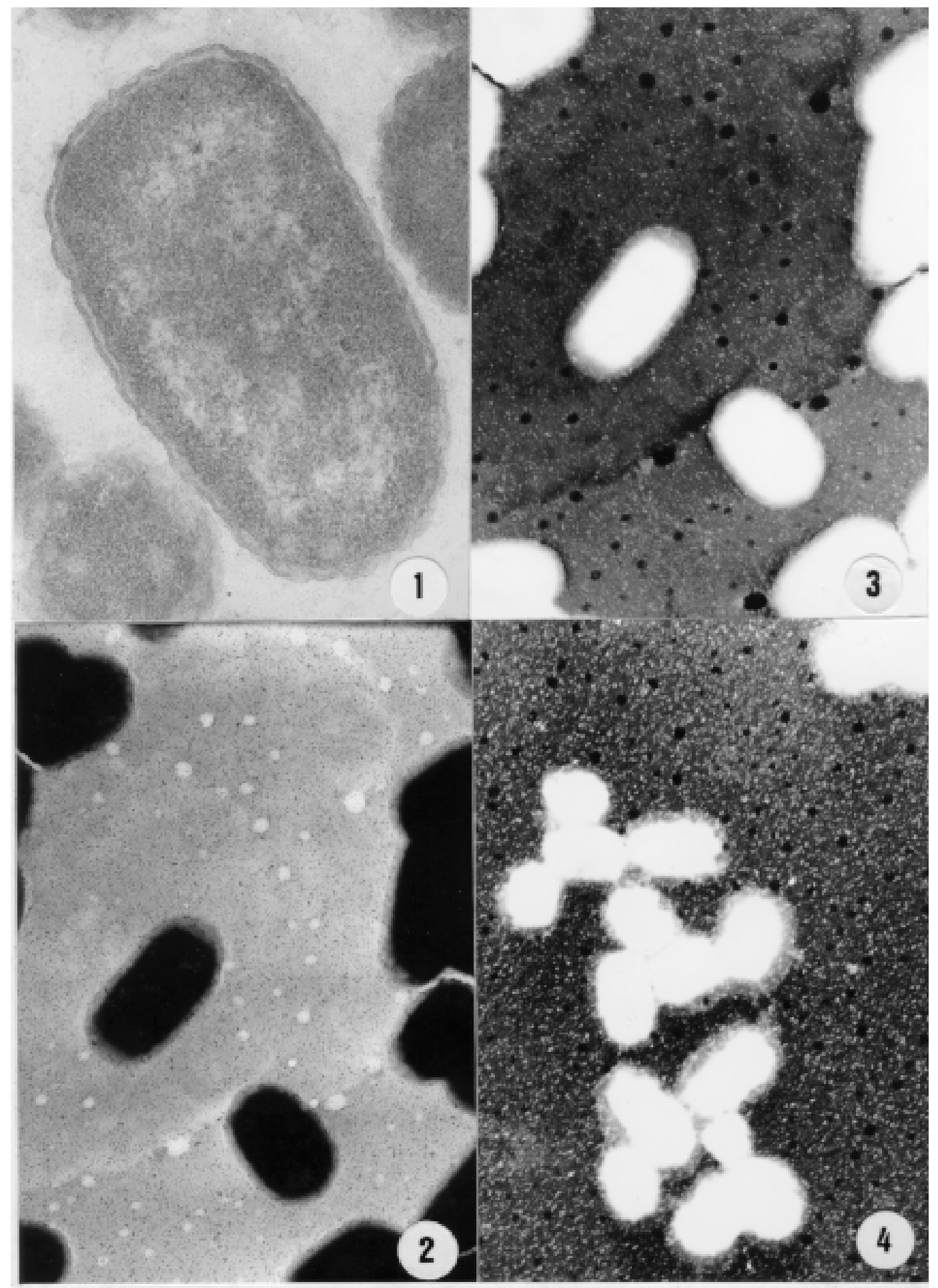

Fig. 1: thin section of enteropathogenic Escherichia coli (EPEC) serotype O111:H2 showing no labeling of cationized ferritin on cell surface. Fig. 2: zero loss filtered image of EPEC serotype O111:H2 before extraction showing a continuous and thick material surrounding individual and colony cells. Fig. 3: inelastic imaging $(\mathrm{E}=20 \Delta \mathrm{eV})$ of EPEC serotype O111:H2 before extraction, showing similar results with a capsule-like structure surrounding the cells. Fig. 4: inelastic imaging $(E=20 \Delta e V)$ showing the same cells after extraction. The structure outside the bacterial cell wall was only partially preserved. 
(Orskov et al. 1977). Our findings related to the detection of anionic residues and neutral sugars such as phosphate, glucose, mannose, rhamnose, galactose, ribose and fucose are in accordance with previous reports which described such residues as components of repeating units devoid or not of aminosugar, acidic sugar and labile substituents (Jann et al. 1978, Hackland et al. 1991, Hahne et al. 1991). The simultaneously detection by colorimetric and GC-MS methods of carbohydrate, protein and phophate residues in the same fraction suggest be components of a unique structure. Bacterial glycoproteins have been demonstrated, and accepet, only recently, as cell envelope components such as membrane-associated glycoproteins, surface-associated glycoproteins and crystalline surface layers (S-layers) as well as secreted glycoproteins and exoenzymes. Although bacterial envelope components are usually constituted of polianionic species, no labeling with cationized ferritin was observed. However, it is known that, during the dehydration steps of routine preparations for electron microscopy, the very heavily hydrated bacterial glycocalyx may collapse and the polymeric matrix may not be preserved (Chan et al. 1982). This could possible explain the non observation of such cationized molecules labeling the bacterial cells surfaces. The electron spectroscopic imaging technique permits to obtain images of thick specimens without the conventional chemical routine procedures. Analysis of these images, before extraction, allowed us to observe the presence of a continuous cell surface-associated structure which was disrupted after extraction suggesting the presence of a structure similar to a bacterial envelope.

The results of the determination of monosaccharide components obtained from the extracted material are in accordance with the data obtained in the lectin agglutination tests using intact bacterial cells. These findings in association with results obtained by transmission electron microscopy, suggest that the materials analyzed are superficial components of the cell surface. Agglutination tests using lectins as probes for the identification of the terminal carbohydrate on the surface of $E$. coli strains suggested the presence of the following sugar units: D-galactose, D-mannose, or mannoselike structures, L-fucose and N-acetyl-D-galactosamine. It should be pointed out that high concentrations of lectins were required to induce agglutination, which may indicate that the bacterial cells investigated are not as rich in surface neutral carbohydrate as most of the eucaryotes already analyzed (Winzler 1970).

Previous results revelead that these strains carry a net negative surface charge due to acidic groups which are suscepible to trypsin and phospholipase
C treatments (Regua Mangia et al. 1995). Such ionogenic surface groups are residues mainly associated with glycoproteins and glycolipid and, in bacteria, these components have been found to be associated to capsular antigens or LPS from outer membranes (Messner 1997). Electronegative charges were also detected in the present study since the major product obtained after fractionation was Fraction A, a fraction that contained acidic compounds obtained by Cetavlon precipitation, a cationic complex .

To our knowledgment the presence of capsular structures have only been described in extraintestinal E. coli strains (Jann \& Jann 1992). However, transmission electron micrographs images associated to physico-chemical analysis performed in the present study suggest the existence of an envelope structure surrounding individual EPEC cells.

The interaction between bacteria and host cells include many specific and non-specific effects (James 1979). Although EPEC has long been known as an important category of diarrheagenic E. coli specific virulence mechanisms, such as bundle-forming pilus and intimin, a $94 \mathrm{Kda}$ outer membrane protein which play an important role in the adherence step to enterocytes, were only recently characterized (Baldwin 1998). Non-specific factors include physico-chemical properties such as surface charge due to specific chemical groups localized on the cell surface.

In summary, this study presents preliminary information on the chemical composition of the cell surface of five EPEC serotypes and on the cellular topology of the components. Additional investigation is needed in order to establish the chemical composition of EPEC capsule-like structures as well as the role played by such components during the interaction of the bacteria with host cells.

\section{ACKNOWLEDGMENTS}

To Dr Ulysses Lins for his help during the analysis of the spectroscopy images, and also to Dr Arnaldo Feitosa Braga de Andrade for his help with lectin agglutination assays. The lectin from Canavalia bonariensis was kindly supplied by Prof. Benildo Sousa Cavada (Departamento de Bioquímica e Biologia Molecular, Universidade Federal do Ceará, Fortaleza, CE, Brasil) .

\section{REFERENCES}

Albert MJ, Faruque SM, Faruque ASG, Neogi PKB, Ansaruzzaman M, Bhuiyan NA, Alam K, Akbar MS 1995. Controlled study of Escherichia coli diarrheal infections in Bangladesh children. J Clin Microbiol 33: 73-977.

Ames BN 1966. Assay of inorganic phosphate total, total phosphate and phosphatases. Meth Enzymol 8: 115-118.

Baldwin TJ 1998. Pathogenicity of enteropathogenic Escherichia coli. J Med Microbiol 47: 283-293. 
Bauer R 1988. Electron spectroscopic imaging advanced technique for imaging and analysis in transmission electron microscopy. Methods Microbiol 20: 113-146.

Chan R, Acres SD, Costerton JW 1982. Use of specific antibody to demonstrate glycocalyx, K99 Pili and the spatial relationship of $\mathrm{K} 99+$ enterotoxigenic Escherichia coli in the ileum of colostrum-fed calves. Infect Immun 37: 170-1180.

Costerton JW, Geesey GG, Cheng KJ 1978. How bacteria stick. Sci Amer 238: 86-95.

Dannon D, Goldstein L, Marikovosky JR, Skutelsky E 1972. Use of cationized ferritin as a label of negative charges on cell surface. J Ultrastruct Res 38 : 500-510.

Donnenberg MS, Kaper JB, Finlay BB 1998. Interactions between enteropathogenic Escherichia coli and host epithelial cells. Trends Microbiol 5: 109-114.

Dubois M, Gilles KA, Hamilton JK, Rebers PA, Smith F 1956. Colorimetric method for determination of sugars and related substances. Anal Chem 28: 350356.

Gomes TAT, Blake PA, Trabulsi LR 1989. Prevalence of Escherichia coli strains with localized, diffuse aggregative adherence to HeLa cells in infants with diarrhea and matched controls. J Clin Microbiol 27: 266-269.

Hackland PL, Parolis H, Parolis LAS 1991. Escherichia coli O9:K38 capsular antigen another ribofuranose containing glycan. Carbohydr Res 230: 193-201.

Hahne M, Jann B, Jann K 1991. Structure of the capsular polysaccharide (K98 antigen) of Escherichia coli O7: K98:H6. Carbohydr Res 230: 245-253.

James AM 1979. Molecular aspects of biological surfaces. Chem Soc Rev 8: 389-418.

Jann K, Jann B 1992. Capsules of Escherichia coli expression and biological significance. Can J Microbiol 38: 705-710.

Jann K, Jann B, Shneider KF, Orskov F, Orskov I 1978. Immunochemistry of $\mathrm{K}$ antigens of Escherichia coli. The K antigens of E. coli O8: K27 (A): H-. Eur J Biochem 5: 456-465.

Lloyd KO 1970. Isolation, characterization and partial structure of peptidogalactomannans from the yeast form of Cladosporium werneckii. Biochem 9: 34463459.

Lowry OH, Rosebrough NJ, Farr AL, Randall RJ 1951. Protein measurement with the folin phenol reagent. J Biol Chem 193: 265-275.

Messner P 1997. Bacterial glycoproteins. Glycoconjugate J 14: 3-11.

Muhldorfer I, Hacker J 1994. Genetic aspects of Escherichia coli virulence. Microbiol Pathogenesis 16: 171181.

Orskov F, Orskov J, Jann B, Jann K 1977. Serology, chemistry and genetics of $\mathrm{O}$ and $\mathrm{K}$ antigens of Escherichia coli. Bacteriol Rev 41: 667-710.

Peterson PK, Quie PG 1981. Bacterial surface components and the pathogenesis of infectious diseases. Ann Rev Med 32: 29-43.

Regua AH, Bravo VLR, Leal MC, Lobo Leite MEL 1990. Epidemiological survey of the enteropathogenic Escherichia coli isolated from children with diarrhoea. J Trop Ped 36: 176-179.

Regua Mangia AH, Duarte AN, Duarte R, Silva L, Bravo VLR, Leal MC 1993. Aetiology of acute diarrhea in hospitalized children in Rio de Janeiro City, Brazil. J Trop Ped 39: 365-367.

Regua Mangia AH, Teixeira LM, Silva-Filho FC 1995. The electrokinetic surface of five enteropathogenic Escherichia coli serogroups. Cell Biophys 26: 45-55.

Sawardeker JS, Sloneker JH, Jeanes A 1965. Quantitative determination of monosaccharides as their alditol acetates by gas liquid chromatography. Anal Chem 37: 1602-1605.

Tamura K, Sakazaki R, Kosako Y 1996. Serotyping and categorization of Escherichia coli strains isolated between 1958 and 1992 from diarrhoeal diseases in Asia. J Med Microbiol 45: 353-358.

Winzler RJ 1970. Carbohydrates in cell surfaces. Int Rev Cytol 29: 77-125.

Wong KH, Skelton SK, Feeley JC 1986. Strain characterization and grouping of Campylobacter jejuni and Campylobacter coli by interaction with lectins. J Clin Microbiol 23: 407-410. 